\title{
Ractopamine levels on performance, carcass characteristics and quality of pig meat ${ }^{1}$
}

\author{
Cesar Augusto Pospissil Garbossa ${ }^{2}$, Raimundo Vicente de Sousa ${ }^{3}$, Vinícius de Souza \\ Cantarelli ${ }^{2}$, Maria Emília de Sousa Gomes Pimenta ${ }^{4}$, Márcio Gilberto Zangeronimo ${ }^{3}$, Hebert \\ Silveira ${ }^{2}$, Thiago Hiroshi Kuribayashi ${ }^{3}$, Luis Gustavo dos Santos Cerqueira ${ }^{2}$
}

\footnotetext{
${ }^{1}$ Financed by MAPA/CNPq.

${ }^{2}$ Departamento de Zootecnia - UFLA.

${ }^{3}$ Departamento de Medicina Veterinária - UFLA.

${ }^{4}$ Departamento de Ciência dos Alimentos - UFLA.
}

\begin{abstract}
This study evaluated the effect of ractopamine (RAC) on the performance of finishing pigs and the meat quality of these animals. Seventy crossbred pigs (35 barrows and 35 females) selected for high gain of lean meat, with initial weight of $77.1 \pm 0.32 \mathrm{~kg}$ were distributed in randomized blocks with five treatments $(0,5,10,15$, and $20 \mathrm{ppm} \mathrm{RAC}$ in the diet) and seven replications during 28 days. The experimental unit was represented by a male and a female pig. Regarding the performance variables, there was a linear increase in final weight with increasing levels of RAC, as well as in average daily weight gain. An improvement in feed conversion was observed for animals fed RAC, and the optimal level - estimated by the LRP model - was $\sim 5$ ppm. For feed intake, no significant effect on intake of digestible lysine and energy intake was observed. Carcass yield responses increased linearly with the RAC dose. Ash content, color component $\mathrm{b}^{*}$ and loss drip linearly decreased with increasing doses of RAC. There was also a significant difference in the percentage of ether extract and crude protein in the loin, and treatment with 20 ppm RAC showed a lower amount of protein and larger amounts of lipids. Moisture content, color component $\mathrm{L}^{*}$, weight loss by cooking and defrosting, shear force and $\mathrm{pH}$ were not affected by the treatment. Concerning the lipid oxidation, there was no effect of RAC on the concentration of TBARS (thiobarbituric acid reactive substances) under cooling and under freezing. Thus, all ractopamine levels improve performance compared with control and do not negatively affect the quality of fresh, chilled or frozen pig meat.
\end{abstract}

Key Words: $\beta$-adrenergic agonist, lipid oxidation, meat quality, TBARS

\section{Introduction}

Historically we have been able to make great strides with regard to the continuous production of food in safe, accessible and in satisfactory quantities. However, according to the Department of Economic and Social Affairs of the UN, the world population will increase from the current 7 billion to over 9 billion in 2050 . Along with the increase in the world population is the economic development of regions such as China, India, Eastern Europe and Latin America, creating a scenario of increasing demand for food (Hines, 2008), especially animal protein.

According to FAO (2007), pork represents $39 \%$ of total world consumption of animal protein, compared with $30 \%$ of chicken, $24 \%$ of beef and $7 \%$ of other types of meat. In this sense, with pork being the animal protein most consumed in the world, both for its ease of processing and for its various options for marketing, consumers impose different requirements in relation to improvement in carcass quality and meat; therefore, different technologies should be used to maximize production.

Among the technologies, ractopamine (RAC) is one of the most used and has positive results in performance, lean meat production and feed efficiency and lower environmental impact. ractopamine is recognized as a beta-adrenergic agonist (ABA) with action of redirecting nutrients, favoring protein synthesis at the expense of fat deposition in the carcass (Gunawan et al., 2007).

However, although there are known benefits of this class of growth promoter with respect to performance and carcass characteristics (Cantarelli et al., 2009), there are still many questions about the optimal dose for use, and industries are concerned with problems related mainly to the quality of meat processing, because they believe there may be formation of free radicals resulting from the intense metabolism that the beta-agonist may cause.

Therefore, the objective of this study was to determine the optimal dose of ractopamine for performance of 
finishing pigs and to evaluate its effect on the quality of meat from animals receiving this additive for 28 days.

\section{Material and Methods}

The experiment was conducted at the Swine Experimental Station of Universidade Federal de Lavras. Thirty-five barrows and 35 gilts, which were hybrids selected for high gain lean tissue, with initial weight of $77.1 \pm 0.32 \mathrm{~kg}$, were housed in groups of two (one male and one female per pen). The temperature of the barn was $19.12 \pm 4.78^{\circ} \mathrm{C}$.

The experimental design was randomized blocks with five treatments $(0,5,10,15$ and $20 \mathrm{ppm}$ RAC), seven replicates, and two animals per experimental unit. For the $\mathrm{pH}$ and lipid oxidation after cooling and freezing, the same design was used, except that the plot was subdivided.

The experimental diets were formulated based on corn and soybean meal supplemented with vitamins, minerals and amino acids to meet the minimum requirements suggested for the strain used, except for lysine, which was increased by $30 \%$ due to the use of ractopamine (Mitchell et al., 1990) (Table 1). Diets were fed ad libitum and weighed daily to determine intake. The animals were weighed at the beginning and end of the experiment to determine the weight gain.

The performance of animals was evaluated through the final weight (FW), feed intake (DFI), daily weight gain (DWG), and feed conversion (FC). After 28 days of supplementation with RAC, the animals were subjected to a solid fasting period of 12 hours and slaughtered in a commercial abattoir.

After being electrically stunned, the animals were exsanguinated and eviscerated. The carcasses were weighed before and after cooling for 24 hours to obtain the carcass yield. To assess the quality of meat, 24 hours after slaughter, samples of the longissimus dorsi muscle were taken from the left side of the carcasses for analysis. From each animal, five samples of longissimus dorsi muscle of $\sim 3 \mathrm{~cm}$ in thickness were removed, in the longitudinal direction. The first cut was used for evaluation of color and weight loss due to dripping; the second cut was used for determining the weight loss by defrosting, weight loss by cooking, and shear force; the third cut was used to test lipid oxidation under cooling; the fourth cut to test lipid oxidation under freezing; and the fifth for determination of the proximate composition of the meat.

The $\mathrm{pH}$ was measured in the longissimus dorsi muscle at the region of the last rib of the left-side carcass 45 minutes after slaughter ( $\mathrm{pH} 45 \mathrm{~min}$ ) and after 24 hours of cooling at $4{ }^{\circ} \mathrm{C}$ (final $\mathrm{pH}$ ).
The water-holding capacity of the meat was evaluated by considering the weight losses by drip, defrosting and cooking. Drip weight loss was evaluated according to the technique described by Boccard et al. (1981), which consists of weighing a $\sim 3 \mathrm{~cm}$ thick sample, keeping it suspended and wrapped in plastic bags for 24 hours, and then re-weighing. The loss by defrosting was obtained by the relationship between the weight of the frozen sample and the weight of sample defrosted for 24 hours at $2 \pm 2{ }^{\circ} \mathrm{C}$. Cooking loss was obtained according to the method described by Bridi \& Silva (2007), which is by the difference between the weight of the defrosted sample and the baked sample $\left(71^{\circ} \mathrm{C}\right.$ internal temperature). The same sample used for evaluation of the loss of water by cooking was used to determine the shear force. Sub-samples of $1.3 \mathrm{~cm}$ diameter, free of fat and connective tissue, were cut.

The shear force was measured perpendicular to the direction of muscle fibers, using a cutting blade in an inverted "V", connected to the texturometer. The speeds used were 5 $\mathrm{mm} / \mathrm{s}$ in the pre-test, $2 \mathrm{~mm} / \mathrm{s}$ in the test, and $5 \mathrm{~mm} / \mathrm{s}$ in the post-test. The results are expressed as the maximum force required for cutting the samples in kilograms-force $(\mathrm{kgf})$ (Bridi \& Silva, 2007).

Table 1 - Proximate composition of diets and calculated values ${ }^{1}$

\begin{tabular}{|c|c|c|c|c|c|}
\hline \multirow{2}{*}{ Ingredients (\%) } & \multicolumn{5}{|c|}{ Doses (ppm) } \\
\hline & 0 & 5 & 10 & 15 & 20 \\
\hline Corn & 71.66 & 71.66 & 71.66 & 71.66 & 71.66 \\
\hline Soybean meal & 23.70 & 23.70 & 23.70 & 23.70 & 23.70 \\
\hline Soybean oil & 1.84 & 1.84 & 1.84 & 1.84 & 1.84 \\
\hline Dicalcium phosphate & 1.08 & 1.08 & 1.08 & 1.08 & 1.08 \\
\hline Limestone & 0.80 & 0.80 & 0.80 & 0.80 & 0.80 \\
\hline Salt & 0.36 & 0.36 & 0.36 & 0.36 & 0.36 \\
\hline Mineral premix ${ }^{2}$ & 0.05 & 0.05 & 0.05 & 0.05 & 0.05 \\
\hline Vitamin premix ${ }^{3}$ & 0.10 & 0.10 & 0.10 & 0.10 & 0.10 \\
\hline DL-methionine $99 \%$ & 0.02 & 0.02 & 0.02 & 0.02 & 0.02 \\
\hline L-lysine $78 \%$ & 0.26 & 0.26 & 0.26 & 0.26 & 0.26 \\
\hline L-threonine 98\% & 0.11 & 0.11 & 0.11 & 0.11 & 0.11 \\
\hline Tylosin ${ }^{4}$ & 0.02 & 0.02 & 0.02 & 0.02 & 0.02 \\
\hline Ractopamine $^{5}$ & 0.00 & 0.025 & 0.050 & 0.075 & 0.100 \\
\hline \multicolumn{6}{|l|}{ Calculated composition } \\
\hline Crude protein $(\%)$ & 16.06 & 16.06 & 16.06 & 16.06 & 16.06 \\
\hline Metabolizable energy (kcal/kg) & 3300 & 3300 & 3300 & 3300 & 3300 \\
\hline Digestible lysine $(\%)$ & 1.002 & 1.002 & 1.002 & 1.002 & 1.002 \\
\hline Digestible methionine (\%) & 0.267 & 0.267 & 0.267 & 0.267 & 0.267 \\
\hline Digestible threonine (\%) & 0.661 & 0.661 & 0.661 & 0.661 & 0.661 \\
\hline Available phosphorus (\%) & 0.300 & 0.300 & 0.300 & 0.300 & 0.300 \\
\hline Calcium $(\%)$ & 0.647 & 0.647 & 0.647 & 0.647 & 0.647 \\
\hline \multicolumn{6}{|c|}{$\begin{array}{l}{ }^{1} \text { Based on tables of requirements for the strain C40 x Topigs Toppi. } \\
{ }^{2} \text { Composition per kg of product: calcium - } 98,800 \mathrm{mg} \text {; cobalt - } 185 \mathrm{mg} \text {; copper - } \\
15,750 \mathrm{mg} \text {; iron - } 26,250 \mathrm{mg} \text {; iodine - } 1,470 \mathrm{mg} \text {; manganese - } 41,850 \mathrm{mg} \text {; zinc - } \\
77,999 \mathrm{mg} \text {. } \\
{ }^{3} \text { Composition per kg of product: folic acid - } 116.55 \mathrm{mg} \text {; pantothenic acid - } 2,333.5 \mathrm{mg} \text {; } \\
\text { biotin - } 5.28 \mathrm{mg} \text {; niacin - 5,600 mg; pyridoxine - } 175 \mathrm{mg} \text {; riboflavin - } 933.3 \mathrm{mg} \text {; } \\
\text { thiamine - } 175 \mathrm{mg} \text {; vitamin A - 1,225.000 IU; Vitamin D3 - 315,000 IU; vitamin } \\
\text { E - } 1,400 \mathrm{mg} \text {; vitamin K3 - } 700 \mathrm{mg} \text {; vitamin B12 - 6,825 mg; selenium - } 105 \mathrm{mg} \text {; } \\
\text { antioxidant - } 1,500 \mathrm{mg} \text {. } \\
{ }^{4} \text { Antibiotic-based granulated tylosin (Tylan). } \\
{ }^{5} 2.05 \% \text { ractopamine hydrochloride (Ractosuin). }\end{array}$} \\
\hline
\end{tabular}


Color was examined in the longissimus dorsi muscle 24 hours after slaughter using a portable Minolta colorimeter model CR-10, with integrating sphere and angle of view $8^{\circ}$, i.e., lighting $\mathrm{d} / 8$ and illuminant $\mathrm{C}$. The components $\mathrm{L}^{*}$ (lightness), $\mathrm{a}^{*}$ (red-green component), and b* (yellow-blue component) are expressed using the CIELAB color system (Konica Minolta Holdings, 1998). Measurements were obtained by moving the device in three different positions, in such a way that practically the whole surface of the meat was sampled. The average reading was used for statistical analysis.

To study the oxidative stability of meat under cooling, the samples of fresh meat were stored in plastic bags, labeled, and stored under refrigeration at approximately $6{ }^{\circ} \mathrm{C}$, and evaluated 24 hours after slaughter (time zero) and on the 5 th, 8 th, and 12 th days of storage. For the evaluation of oxidative stability of the meat under freezing, samples were stored in the same way but at a temperature of $-18^{\circ} \mathrm{C}$ and evaluated at time zero, and during the 15th, 30th, 60th, and 90th days.

Analyses of TBARS (thiobarbituric acid reactive substances) were performed according to the methodology described by Tarladgis (1964).

After the test of normality (Shapiro-Wilk), the variables of performance, carcass, and meat were subjected to analysis of variance, which, when significant, were subjected to regression analysis for the doses of ractopamine. For ash, lipids, b* color component, weight loss by cooking, weight loss by drip, and lipid oxidation under cooling and freezing the square root transformation option was used. The split plot design for the assessment of lipid oxidation and $\mathrm{pH}$ was used. When the effect was cubic or quartic, the mean doses were compared by the SNK test at 5\%. To evaluate the variable feed conversion, the regression discontinuity model LRP (linear response plateau) to estimate the optimal level of RAC was used. All statistical analyses were performed using the computer program SAS (Statistical Analyses System, version 9.1).

\section{Results and Discussion}

Supplementation with RAC to pigs resulted in higher $(\mathrm{P}<0.05)$ final weight and average daily weight gain, and improved feed conversion (Table 2), demonstrating the ability of this additive to improve the performance of finishing pigs. A linear effect was observed for final weight $(\mathrm{P}<0.05)$; animals fed diets with 20 ppm supplement weighed $4.19 \%$ more than animals on control. Similar results were found by Carr et al. (2009), testing levels of 0 , 5,10 , and 20 ppm RAC for heavy fattening pigs $(133 \mathrm{~kg})$. Moore et al. (2009) observed a higher final weight of the treated animals compared with control when supplementing RAC for 26 days ( 5 ppm RAC for the first 14 days, and 10 ppm RAC for the12 subsequent days).

However, Rikard-Bell et al. (2009) evaluated animals receiving RAC during 31 days (5 ppm RAC for 14 days and 10 ppm RAC for 17 days) and Sanches et al. (2010) tested $0,5,10$, and $20 \mathrm{ppm}$ RAC for barrows, and found no difference in final weight. With respect to the average daily weight gain, there was a significant effect of RAC with a linear increase in gain. Compared with control, $20 \mathrm{ppm}$ RAC increased weight gain by $18.87 \%$. Similar results were also reported by Watkins et al. (1990) $(0,5,10,15$ and 20 ppm RAC for 45 or 50 days) and by Armstrong et al. (2004) $(0,5,10$ and 20 ppm RAC in periods ranging from 6 to 34 days). However, data obtained in this experiment differ from those observed by Brumm et al. (2004) who evaluated 0 and 10 ppm RAC for barrows for 28 days, and those by Mimbs et al. (2005), who tested genetic groups (slightly fat or fat) supplemented with 0 or 10 ppm RAC for 28 days, and did not find a significant increase in weight gain of animals.

Table 2 - Performance and carcass traits of fattening pigs receiving different doses of ractopamine in the diet $(0,5,10,15$, and $20 \mathrm{ppm})$ for 28 days

\begin{tabular}{|c|c|c|c|c|c|c|c|}
\hline \multirow{2}{*}{ Variable } & \multicolumn{5}{|c|}{ Doses (ppm) } & \multirow{2}{*}{ Mean } & \multirow{2}{*}{$\mathrm{CV}(\%)$} \\
\hline & 0 & 5 & 10 & 15 & 20 & & \\
\hline Final weight $(\mathrm{kg})^{2}$ & 102.70 & 105.30 & 106.50 & 105.60 & 107.00 & 105.40 & 2.52 \\
\hline Daily weight gain ${ }^{1,3}$ & 901 & 1023 & 1050 & 1012 & 1071 & 1011 & 8.22 \\
\hline Daily feed intake ${ }^{1}$ & 2823 & 2741 & 2871 & 2746 & 2919 & 2820 & 8.55 \\
\hline Feed conversion ${ }^{4}$ & 3.15 & 2.68 & 2.73 & 2.76 & 2.87 & 2.84 & 4.47 \\
\hline Daily intake of digestible lysine ${ }^{1}$ & 29.08 & 28.24 & 29.58 & 28.28 & 30.06 & 29.00 & 8.55 \\
\hline Daily intake of metabolizable energy (kcal/day) & 9118 & 8855 & 9275 & 8869 & 9427 & 9109 & 8.55 \\
\hline Carcass yield $(\%)^{2}$ & 80.70 & 81.00 & 81.10 & 81.80 & 81.70 & 81.30 & 1.16 \\
\hline
\end{tabular}

$\mathrm{CV}$ - coefficient of variation.

${ }^{1} \mathrm{~g} /$ day.

${ }^{2}$ Significant linear regression $(\mathrm{P}<0.05)$.

${ }^{3}$ Significant linear regression $(\mathrm{P}<0.01)$.

${ }^{4}$ Linear response plateau. 
The average daily feed intake of animals supplemented with RAC did not differ between treatments $(\mathrm{P}>0.05)$, similar to the observed by Aalhus et al. (1992) $(0,5,10,15$ and 20 ppm RAC for barrows and gilts) and Marinho et al. (2007) ( 5 ppm RAC for 21 or 28 days for barrows). However, this behavior was not observed by Carr et al. (2005a) and Mimbs et al. (2005), suggesting that these differences in responses may be related to the different genetic strains used.

Regarding the variable feed conversion, the optimum supplementation of ractopamine estimated by the LRP model was $3.88 \mathrm{ppm}$, resulting in a feed conversion value of $2.78(\mathrm{P}<0.05)$. Using the optimal level estimated by the LRP model, the improvement in feed conversion compared with the control treatment was $29 \%$. Similar results were found by Ferreira et al. (2011) $(0,5,10,15$ and 20 ppm RAC for barrows and gilts), who estimated the optimal level of $4.41 \mathrm{ppm}$ RAC for better feed conversion. Similar results were also found by Schinckel et al. (2001), who concluded that to gain weight, most of the animal response to RAC can be achieved with supplementation of $5 \mathrm{ppm}$ in the diet. Other authors, however, observed different responses: Armstrong et al. (2004) (0, 5, 10, and 20 ppm RAC) observed a significant response to the improvement in feed conversion in all treatments, although more efficiently for 10 and 20 ppm RAC; Stites et al. (1991) observed that the effect of RAC in pigs does not necessarily present a dosedependent behavior, which may partly explain the results obtained in this work.

Some researchers, such as Kessler (2001), claim that the feed conversion is highly correlated with variables representing the gain of lean tissue and, on that basis, persists as a performance measure and is used as the main reference for evaluating the efficiency of pig production systems. By presenting a lower energy value aggregate, the greater gain of lean tissue improves the response in relation to feed conversion.

The greater feed conversion observed in animals receiving RAC may explain their better performance compared with the higher final weight and better average daily weight gain. This is because RAC is recognized as a splitter of nutrients, favoring a lower fat deposition and increased deposition of lean tissue in the carcass, whereas the muscle tissue is rich in water, and so demands fewer nutrients for their formation. The energetic deposition of muscle tissue is approximately three times lower than the cost of body fat deposition (English et al., 1988).

In general, divergent responses observed in the literature can be explained by different studies using varied strains and duration of use of the additive as well as the nutritional management (Dunshea et al., 1993; Smith et al., 1995).
No differences $(\mathrm{P}>0.05)$ were observed for consumption of digestible lysine and energy intake, demonstrating that the differences observed were not influenced by these factors.

For carcass yield, there was a linear increase $(\mathrm{P}<0.05)$ with increased doses of RAC in the diet. The animals fed 20 ppm RAC had a yield $1.24 \%$ higher than the control treatment. According to Mills (2002), and Stahly \& Barck (1991), ractopamine and other phenylethanolamines that increase the percentage of meat are capable of increasing the proportion of nutrients deposited on the carcass in relation to the deposition on the internal organs. One of the reasons for this improvement in carcass yield is the occurrence of a higher weight at slaughter with low relative weight of the viscera, generating an increase in muscle mass and a decrease in visceral weight. Adeola et al. (1990) (supplementing barrows and gilts with 20 ppm RAC for 28 days) and Stites et al. (1991) (48 days of 0, 5, 10, or 20 ppm RAC for finishing pigs) observed the same effect on an increase in the carcass weight for animals receiving the additive.

However, when evaluating the supplementation of $20 \mathrm{ppm}$ RAC to barrows and gilts from 64 to $100 \mathrm{~kg}$, Carr et al. (2005a) and Uttaro et al. (1993) found no significant difference for animals receiving the additive. However, in order for comparisons of carcass yield values obtained in different scientific studies to be valid, the income must have been determined under similar conditions, since this variable is highly affected by the duration of pre-operative fasting before slaughter, as well as by the diet of animals (Oliveira, 2005).

The centesimal composition of longissimus dorsi shows that there was no difference $(\mathrm{P}>0.05)$ between treatments for moisture (Table 3 ). On average, the muscle showed $72.5 \%$ moisture, which is in accordance with Estevez et al. (2003) and Virgili et al. (2003), who found average moisture of $73 \%$. There was no significant difference $(\mathrm{P}>0.05)$ in mean percentage of crude protein and ether extract for the longissimus dorsi muscle from pigs that received the control diet or diets containing 5, 10 or 15 ppm RAC. However, pigs fed diets containing 20 ppm RAC had a lower average percentage of crude protein and a higher average percentage of lipids $(\mathrm{P}<0.05)$ in this muscle compared with animals receiving other treatments. The decrease in the percentage of protein in the muscle of animals receiving the highest level of ractopamine was consistent since there was a concomitant increase in the ether extract.

The deposition of water is related to muscle protein synthesis, and inversely related to fat deposition. Dunshea et al. (1993) and Uttaro et al. (1993) found more protein deposition and higher moisture content with the inclusion of ractopamine in the diet. 
Since the effect of ractopamine on lipid metabolism and protein synthesis occurs by binding to membrane receptors, it can be inferred that these results occurred due to the phenomenon of "down-regulation" or desensitization of $\beta$-adrenergic receptors, in excess of the additive, but it must be emphasized that this behavior is not similar in other muscles.

Evaluating the use of 0,10 and $20 \mathrm{ppm}$ RAC for barrows, Carr et al. (2005b) observed an increase in the amount of ether extract of the longissimus dorsi muscle of pigs, comparing the treatment of $20 \mathrm{ppm}$ RAC with others. Some other researchers (Apple et al., 2008; Xiao et al., 1999) found that animals supplemented with $20 \mathrm{ppm}$ RAC had a greater marbling score of the longissimus dorsi muscle, which is consistent with the observed in this experiment.

The ash content of the longissimus dorsi muscle was influenced by the use of ractopamine. There was a linear effect $(\mathrm{P}<0.05)$, in which the animals treated with higher doses of the additive had lower percentages of ash. Comparing the dose of $20 \mathrm{ppm}$ RAC with the control, there was a decrease of $\sim 10.35 \%$ of ash. Adeola et al. (1990) also observed a decrease in the levels of ash in animals supplemented with $20 \mathrm{ppm}$ RAC when compared with untreated control. However, Uttaro et al. (1993) and Xiao et al. (1999) observed an increase in ash content of the muscle of fattening pigs with an initial weight of $64 \mathrm{~kg}$ and a final weight of $90 \mathrm{~kg}$ supplemented with $20 \mathrm{ppm}$ RAC.

There were no significant differences $(\mathrm{P}>0.05)$ between treatments for initial and final $\mathrm{pH}$ (Table 4). These values are within the normal reported in the literature and are similar to those of Bridi et al. (2006), Carr et al. (2005b, 2009) and Stites et al. (1991). More specifically in relation to the final $\mathrm{pH}$, the mean values were very close to those considered optimal by Dalla Costa (2010) for fresh meat of pigs (pH between 5.5 and 5.8). However, Warris et al. (1990) found that the final $\mathrm{pH}$ of the meat from pigs treated with $\beta$-adrenergic agonist was higher, and these results justify the fact that these animals consumed muscle glycogen, which can result in lower production and accumulation of lactic acid in the carcass after slaughter, thereby making it difficult to reduce the $\mathrm{pH}$.

Regarding the variables of color, there was no significant difference $(\mathrm{P}>0.05)$ for $\mathrm{L}^{*}$. Carr et al. $(2005 \mathrm{a}, \mathrm{b})$ and Uttaro et al. (1993) also found no significant difference for this variable. All values of $\mathrm{L}^{*}$ found in this study were higher than 50, indicating that the lighter meats were considered normal (Joo et al., 1995, 1999), including those

Table 3 - Centesimal composition of the longissimus dorsi muscle of finishing pigs receiving different doses of ractopamine in the diet $(0,5,10,15$, and $20 \mathrm{ppm})$ for 28 days

\begin{tabular}{|c|c|c|c|c|c|c|c|}
\hline \multirow{2}{*}{ Variable } & \multicolumn{5}{|c|}{ Doses (ppm) } & \multirow{2}{*}{ Mean } & \multirow{2}{*}{$\mathrm{CV}(\%)$} \\
\hline & 0 & 5 & 10 & 15 & 20 & & \\
\hline Moisture & 72.47 & 72.61 & 72.49 & 72.16 & 72.74 & 72.50 & 1.06 \\
\hline Crude protein ${ }^{1}$ & $18.03 \mathrm{a}$ & $18.16 \mathrm{a}$ & $17.91 \mathrm{a}$ & $19.85 a$ & $15.91 b$ & 17.97 & 7.96 \\
\hline Ether extract ${ }^{1}$ & $6.26 \mathrm{a}$ & $5.57 \mathrm{a}$ & $6.27 \mathrm{a}$ & $5.04 \mathrm{a}$ & $11.34 \mathrm{~b}$ & 6.90 & 9.38 \\
\hline $\mathrm{Ash}^{2}$ & 3.96 & 3.80 & 3.75 & 3.82 & 3.55 & 3.78 & 3.37 \\
\hline
\end{tabular}

$\mathrm{CV}$ - coefficient of variation.

${ }^{1}$ Means followed by different letters in the same row differ by the SNK test $(\mathrm{P}<0.05)$.

${ }^{2}$ Significant linear regression $(\mathrm{P}<0.05)$.

Table 4 - Initial $\mathrm{pH}$, final $\mathrm{pH}$, color components $\left(\mathrm{L}^{*}, \mathrm{a}^{*}\right.$ and $\left.\mathrm{b}^{*}\right)$ and physical characteristics of longissimus dorsi muscle of fattening pigs receiving different doses of ractopamine in the diet $(0,5,10,15$, and $20 \mathrm{ppm})$ for 28 days

\begin{tabular}{|c|c|c|c|c|c|c|c|}
\hline \multirow{2}{*}{ Variable } & \multicolumn{5}{|c|}{ Doses (ppm) } & \multirow{2}{*}{ Mean } & \multirow{2}{*}{ CV (\%) } \\
\hline & 0 & 5 & 10 & 15 & 20 & & \\
\hline Initial $\mathrm{pH}$ & 6.06 & 5.90 & 6.13 & 6.03 & 6.11 & 6.04 & 3.44 \\
\hline Final pH & 5.83 & 5.76 & 5.83 & 5.84 & 5.75 & 5.80 & 1.95 \\
\hline $\mathrm{L}^{*}$ & 52.2 & 51.7 & 51.2 & 51.8 & 51.7 & 52.0 & 3.43 \\
\hline$a^{* 1}$ & 7.86 & 6.88 & 6.91 & 6.79 & 6.98 & 7.08 & 6.82 \\
\hline$b^{* 2}$ & 1.16 & 0.75 & 0.46 & 0.62 & 0.57 & 0.71 & 24.82 \\
\hline Drip loss $(\%)^{2}$ & 1.16 & 1.11 & 0.93 & 0.95 & 0.95 & 1.02 & 7.75 \\
\hline Weight loss by defrosting (\%) & 2.79 & 2.91 & 3.20 & 3.00 & 3.05 & 2.99 & 30.36 \\
\hline Weight loss by cooking (\%) & 26.8 & 26.7 & 27.4 & 29.6 & 27.7 & 28.0 & 4.49 \\
\hline Shear force (Kgf) & 7.36 & 7.61 & 6.64 & 7.00 & 8.08 & 7.34 & 8.83 \\
\hline
\end{tabular}

$\mathrm{CV}$ - coefficient of variation.

${ }^{1}$ Significant quadratic regression $(\mathrm{P}<0.05)$

2 Significant linear regression $(\mathrm{P}<0.05)$. 
from the control treatment. This fact alone is not sufficient to consider them as PSE (pale, soft, and exudative), since to be regarded as such, the following also needs to be present: initial $\mathrm{pH}$ lower than 5.8, final $\mathrm{pH}$ below 5.6 and loss of water by freezing greater than 5\% (Joo et al., 1995, 1999). This finding is of extreme importance, since it reaffirms that supplementation of ractopamine to finishing pigs does not favor the production of meat as PSE. This defect of pork has great economic impact, since it is unsuitable for industrialization and is unpleasant for the consumer. Increased values of $\mathrm{L}^{*}$ are related to the low final $\mathrm{pH}$ of the meat, characteristic of animals with rapid anaerobic consumption of glycogen, resulting in greater lactic acid production. The accumulation of lactic acid starts the denaturation of meat proteins, resulting in greater loss of water and greater reflection of light, giving it a pale appearance (Juncher et al., 2001).

For $\mathrm{a}^{*}$, a quadratic effect was observed $(\mathrm{P}<0.05)$ and for $b^{*}$ a linear effect $(P<0.05)$ was observed, i.e., the value of $a^{*}$ decreased close to the treatment with $15 \mathrm{ppm}$ ractopamine inclusion in the diet and at the level of $20 \mathrm{ppm}$ RAC increased again, showing behavior similar to that presented for the percentage of lipids in the longissimus dorsi muscle. Higher values for $\mathrm{a}^{*}$ can be explained by the amount of iron present in the tissue, where samples with the highest amount of potassium show higher values of a* (Juncher et al., 2001), which is associated with this quantity of myoglobin in muscle. Several studies have shown that ractopamine promotes significant reductions in the $\mathrm{a}^{*}$ values (Uttaro et al., 1993; Carr et al., 2005b). Regarding the $b^{*}$ values, they decreased linearly with the inclusion of ractopamine in the diet. In general, the value of $b *$ indicates carotenoid pigments that are deposited in fat (Bressan et al., 2004).

Due to the tendency of pigs to have higher fat deposition in the subcutaneous layer and later in muscle, the slaughter of heavier animals can result in changes in the values of $b^{*}$ (Cisneros et al., 1996). In addition, changes in the $b^{*}$ value can be indicative of changes in fatty acid composition of intramuscular fat (John et al., 2005). Aalhus et al. (1990), Carr et al. (2005a) and Uttaro et al. (1993) reported similar results, with increased levels of ractopamine leading to a decrease in the $b^{*}$ value. According to Apple et al. (2007), although there were significant differences in the color of pig meat, these differences are usually not visibly noticeable to consumers in most cases. Moreover, there are studies showing that supplementation of pigs with 5,10 , or $20 \mathrm{ppm}$ RAC did not affect the color of meat (Stites et al., 1991; Armstrong et al., 2004).
Drip weight loss decreased linearly $(\mathrm{P}<0.05)$ with the use of increasing doses of ractopamine. Treatment with $20 \mathrm{ppm}$ RAC led to a decrease in weight loss of $18.10 \%$ when compared with control. Apple et al. (2004), Bridi et al. (2006) and Stoller et al. (2003) observed no change in this variable. However, it is interesting to note that the drip loss influences the industrial processing of meat (Roça, 2010). The amount of water loss is a problem for industries as the exudate contains soluble proteins, vitamins and minerals (Bonagurio et al., 2003). Thus, the result of this research indicates that ractopamine favors the production of noble products such as cooked and raw ham, and also that after the cuts for the sale, the product looks better to consumers for presenting a lower accumulation of water in containers. Agostini et al. (2011) found no effect of ractopamine dose used on drip loss.

The values for shear force were not significantly different $(\mathrm{P}>0.05)$ when using increasing doses of ractopamine in the diet of pigs. Bridi et al. (2006) and Agostini et al. (2011) found no effect of ractopamine on this variable, showing that the use of ractopamine did not affect the tenderness of the meat. Other studies have shown differences (Warris et al., 1990; Wood et al., 1994), i.e., it was observed that pigs that had consumed ractopamine showed meat with a higher shear force, possibly as a result of the increasing diameter of muscle fibers or by reducing the activity of the proteolytic enzyme calpain.

TBARS values were not affected by different levels of ractopamine, and there was no interaction between ractopamine and storage time (Table 5). However, the storage time led to an increase $(\mathrm{P}<0.01)$ in TBARS values, agreeing with the results observed by Apple et al. (2008), who evaluated the longissimus dorsi muscle of animals receiving 0 or 20 ppm RAC, and no difference between the levels of ractopamine for this variable was observed. However, there was an increase in TBARS values in relation to storage time. Likewise, Leick et al. (2010) tested the levels of 0 or 5 ppm RAC and observed no difference in TBARS values of the longissimus dorsi muscle packaged under modified atmosphere $\left(80 \% \mathrm{O}_{2} / 20 \% \mathrm{CO}_{2}\right)$ for $0,7,14$ and 21 days.

As occurred with the meat under cooling, a significant linear effect $(\mathrm{P}<0.01)$ of the variable time was observed, i.e., TBARS also increased with time (Table 6). However, TBARS values were lower than the literature cites as being detectable by the consumer, thus determining that the meat from RAC-supplemented pigs could be stored for a period of 90 days without having its quality compromised in terms of lipid oxidation. 
Table 5 - Lipid oxidation (malonic dialdehyde concentration in $\mathrm{mg} / \mathrm{kg}$ ) of longissimus dorsi muscle of fattening pigs receiving different doses of ractopamine in the diet $(0,5,10,15$, and $20 \mathrm{ppm})$ and stored under refrigeration for $0,5,8$, and 12 days

\begin{tabular}{|c|c|c|c|c|c|c|c|c|c|}
\hline \multirow{2}{*}{ Day of evaluation } & \multicolumn{5}{|c|}{ Doses of ractopamine (ppm) } & \multirow{2}{*}{ Mean $^{1}$} & \multicolumn{3}{|c|}{$\mathrm{P}$} \\
\hline & 0 & 5 & 10 & 15 & 20 & & Ractopamine & Time & $\mathrm{R} * \mathrm{~T}$ \\
\hline 0 & 0.117 & 0.128 & 0.106 & 0.099 & 0.124 & 0.115 & 0.3879 & $\leq 0.0001$ & 0.9893 \\
\hline 5 & 0.269 & 0.267 & 0.254 & 0.241 & 0.216 & 0.249 & & & \\
\hline 8 & 0.458 & 0.424 & 0.431 & 0.361 & 0.384 & 0.412 & & & \\
\hline 12 & 0.598 & 0.618 & 0.505 & 0.513 & 0.482 & 0.543 & & & \\
\hline Mean & 0.360 & 0.359 & 0.324 & 0.304 & 0.301 & & & & \\
\hline CV $(\%)$ & 16.18 & & & & & & & & \\
\hline
\end{tabular}

$\mathrm{CV}$ - coefficient of variation; $\mathrm{R} * \mathrm{~T}-$ ractopamine $\times$ time interaction.

${ }^{1}$ Significant linear regression $(\mathrm{P}<0.05)$.

Table 6 - Lipid oxidation (malonic dialdehyde concentration in $\mathrm{mg} / \mathrm{kg}$ ) of longissimus dorsi muscle of finishing pigs receiving different doses of ractopamine in the diet $(0,5,10,15$, and $20 \mathrm{ppm})$ and frozen for $0,15,30,60$, and 90 days

\begin{tabular}{|c|c|c|c|c|c|c|c|c|c|}
\hline \multirow{2}{*}{ Day of evaluation } & \multicolumn{5}{|c|}{ Doses of ractopamine (ppm) } & \multirow{2}{*}{ Mean $^{1}$} & \multicolumn{3}{|c|}{$\mathrm{P}$} \\
\hline & 0 & 5 & 10 & 15 & 20 & & Ractopamine & Time & $\mathrm{R} * \mathrm{~T}$ \\
\hline 0 & 0.117 & 0.128 & 0.106 & 0.134 & 0.114 & 0.120 & 0.8208 & $\leq 0.0001$ & 0.6239 \\
\hline 15 & 0.104 & 0.101 & 0.096 & 0.083 & 0.096 & 0.096 & & & \\
\hline 30 & 0.138 & 0.137 & 0.144 & 0.116 & 0.130 & 0.133 & & & \\
\hline 60 & 0.173 & 0.169 & 0.163 & 0.140 & 0.158 & 0.161 & & & \\
\hline 90 & 0.225 & 0.229 & 0.217 & 0.196 & 0.239 & 0.221 & & & \\
\hline Mean & 0.151 & 0.153 & 0.145 & 0.134 & 0.148 & & & & \\
\hline CV (\%) & 9.91 & & & & & & & & \\
\hline
\end{tabular}

$\mathrm{CV}$ - coefficient of variation; $\mathrm{R} * \mathrm{~T}-$ ractopamine $\times$ time interaction.

${ }^{1}$ Significant linear regression $(\mathrm{P}<0.05)$.

\section{Conclusions}

All ractopamine levels improve feed conversion in the same way compared with control. For the variables daily gain, final weight and carcass yield, linear effect was observed with increasing doses up to $20 \mathrm{ppm}$ of ractopamine. Ractopamine does not negatively affect the quality of pork, bringing benefits to both producers and slaughterhouses.

\section{References}

AALHUS, J.L.; JONES, S.D.M.; SCHAEFER, A.L. et al. The effect of ractopamine on performance, carcass composition and meat quality of finishing pigs. Canadian Journal of Animal Science, v.70, p.943-952, 1990.

AALHUS, J.L.; SCHAEFER, A.L.; MURRAY, A.C. et al. The effect of ractopamina on myofibre distribution and morphology and their relation to meat quality in swine. Meat Science, v.31, p.397-409, 1992.

ADEOLA, O.; DARKO, E.A.; HE, P. et al.Manipulation of porcine carcass composition by ractopamine. Journal of Animal Science, v.68, p.3633-3641, 1990.

AGOSTINI, P.S.; SILVA, C.A.; BRIDI, A.M. et al. Efeito da ractopamina na performance e na fisiologia do suíno. Archivos de Zootecnia, v.60, p.659-670, 2011.

APPLE, J.K.; MAXWELL, C.V.; BROWN, D.C. et al. Effects of dietary lysine and energy density on performance and carcass characteristics of finishing pigs fed ractopamine. Journal of Animal Science, v.82, p.3277-3287, 2004.

APPLE, J.K.; MAXWELL, C.V.; KUTZ, B.R. et al. Interactive effect of ractopamine and dietary fat source on pork quality characteristics of fresh pork chops during simulated retail display. Journal of Animal Science, v.86, p.2717-2722, 2008.

APPLE, J.K.; RINCKER, P.J.; MCKEITH, F.K. et al. Review: metaanalysis of the ractopamine response in finishing swine. The Professional Animal Scientist, v.23, p.179-196, 2007.

ARMSTRONG, T.A.; IVERS, D.J.; WAGNER, J.R. et al. The effect of dietary ractopamine concentration and duration of feeding on growth performance, carcass characteristics, and meat quality of finishing pigs. Journal of Animal Science, v.82, p.3245-3253, 2004.

BOCCARD, R.; BUCHTER, L.; CASTEELS, E. et al. Procedures for measuring meat quality characteristics in beef production experiments. Livestock Production Science, v.8, p.385-397, 1981.

BONAGURIO, S.; PÉREZ, J.R.O.; GARCIA, I.F.F. et al. Qualidade de carne de cordeiros Santa Inês puros e mestiços com Texel abatidos com diferentes pesos. Revista Brasileira de Zootecnia, v.32, p.1981-1991, 2003.

BRESSAN, M.C.; JARDIM, N.S.; PÉREZ, J.R.O. et al. Influência do sexo e faixas de peso ao abate nas características físico-químicas da carne de capivara. Ciência e Tecnologia de Alimentos, v.24, p.357-362, 2004.

BRIDI, A.M.; SILVA, C.A. Métodos de avaliação da carcaça e da carne suína. Londrina: Midiograf, 2007. 97p.

BRIDI, A.M.; OLIVEIRA, A.R.; FONSECA, N.A.N. et al. Efeito do genótipo halotano, da ractopamina e do sexo do animal na qualidade da carne suína. Revista Brasileira de Zootecnia, v.35, p.2027-2033, 2006.

BRUMM, M.C.; MILLER, P.S.; THALER, R.C. Response of barrows to space allocation and ractopamine. Journal of Animal Science, v.82, p.3373-3379, 2004.

CANTARELLI, V.S.; FIALHO, E.T.; ALMEIDA, E.C. etal. Características da carcaça e viabilidade econômica do uso de cloridrato de ractopamina para suínos em terminação com alimentação à vontade ou restrita. Ciência Rural, v.39, n.3, p.844-851, 2009. 
CARR, S.N.; RINCKER, P.J.; KILLEFER, J. et al. Effects of different cereal grains and ractopamine hydrochloride on performance, carcass characteristics, and fat quality in late-finishing pigs. Journal of Animal Science, v.83, p.223-230, 2005a.

CARR, S.N.; IVERS, D.J.; ANDERSON, D.B. et al. The effects of ractopamine hydrochloride on lean carcass yields and pork quality characteristics. Journal of Animal Science, v.83, p.2886-2893, 2005 b.

CARR, S.N.; HAMILTON, D.N.; MILLER, K.D. et al. The effect of ractopamine hydrochloride (Paylean ${ }^{\circledR}$ ) on lean carcass yields and pork quality characteristics of heavy pigs fed normal and amino acid fortified diets. Meat Science, v.81, p.533-539, 2009.

CISNEROS, F.; ELLIS, M.; MCKEITH, F.K. et al. Influence of slaughter weight on growth and carcass characteristics, commercial cutting and curing yields, and meat quality of barrows and gilts from two genotypes. Journal of Animal Science, v.74, p.925-933, 1996.

DALLA COSTA. O.A.; LUDKE, J.V.; COSTA, M.J.R.P. et al. Efeito das condições pré-abate sobre a qualidade da carne de suínos pesados. Archivos de Zootecnia, v.59, p.391-402, 2010 .

DUNSHEA, F.R.; KING, R.H.; CAMPBELL, R.G. et al. Interrelationships between sex and ractopamine on protein and lipid deposition in rapidly growing pigs. Journal of Animal Science, v.71, p.2919-2930, 1993.

ENGLISH, P.R.; FOWLER, S.; BAXTER, S. et al. The basis of efficient systems for the growing-finishing pig. In: The growing and finishing pig: improving efficiency. [S. 1.]: Farming, 1988. p.555.

ESTEVEZ, M.; MORCUENDE, D.; CAVA LÓPEZ, R. Physicochemical characteristics of M. longissimus dorsi from three lines of free-range reared Iberian pigs slaughtered at $90 \mathrm{~kg}$ live-weight and commercial pigs: a comparative study. Meat Science, v.64, p.499-506, 2003.

FAO. [2007]. Food and Agriculture Organization of the United Nations. Available at: <http://www.fao.org>. Accessed on: July 30, 2012.

FERREIRA, M.S.S.; SOUSA, R.V.; SILVA, V.O. et al. Cloridrato de ractopamina em dietas para suínos em terminação. Acta Scientiarum, v.33, p.25-32, 2011.

GUNAWAN, A.M.; RICHERT, B.T.; SHINCKEL, A.P. et al. Ractopamine induces differential gene expression in porcine skeletal muscles. Journal of Animal Science, v.85, p.2115-2124, 2007.

HINES, A. Consumer trends in three different worlds. The Futurist, v.42, p. $18-23,2008$

JOHN, L.; CORNFORTH, D.P.; CARPENTER, C.E. et al. Color and thiobarbituric acid values of cooked top sirloin steaks in modified atmospheres of $80 \%$ oxygen, or $0.4 \%$ carbon monoxide, or vacuum. Meat Science, v.69, p.441-449, 2005.

JOO, S.T.; KAUFFMAN, R.G.; KIM, B.C. The relationship between color and water holding capacity in post rigor porcine longissimus muscle. Muscle Foods, v.6, p.211-226, 1995.

JOO, S.T.; KAUFFMAN, R.G.; KIM, B.C. The relationship of sarcoplasmic and myofibrillar protein solubility to colour and water-holding capacity in porcine longissimus muscle. Meat Science, v.52, p.291-297, 1999.

JUNCHER, D.; RONN, B.; MORTENSEN, E. et al. Effect of preslaughter physiological conditions on the oxidative stability of colour and lipid during chill storage of pork. Meat Science, v.58, p.347-357, 2001.

KESSLER, A.M. O significado da conversão alimentar para suínos em crescimento: sua relevância para modelagem e características de carcaça. In: CONFERÊNCIA INTERNACIONAL VIRTUAL SOBRE QUALIDADE DE CARNE SUÍNA, 2., 2001, Concórdia. Anais... Concórdia: EMBRAPA-CNPSA, 2001. p.375-384.

KONICA MINOTA HOLDINGS. Precise color communication: color control from perception to instrumentation. Japan. Osaka, 1998. p.19.

LEICK, C.M.; PULS, C.L.; ELLIS, M. et al. Effect of distillers dried grains with solubles and ractopamine (Paylean) on quality and shelf-life of fresh pork and bacon. Journal of Animal Science, v.88, p.2751-2766, 2010.
MARINHO, P.C.; FONTES, D.O.; SILVA, F.C.O. et al. Efeito da ractopamina e de métodos de formulação de dietas sobre o desempenho e as características de carcaça de suínos machos castrados em terminação. Revista Brasileira de Zootecnia, v.36, p.1061-1068, 2007.

MILLS, S.E. Biological basis of the ractopamine response. Journal of Animal Science, v.80, p.28-32, 2002.

MIMBS, K.J.; PRINGLE, T.D.; AZAIN, M.J. et al. Effects of ractopamine on performance and composition of pigs phenotypically sorted into fat and lean groups. Journal of Animal Science, v.83, p.1361-1369, 2005.

MITCHELL, A.D.; SOLOMON, M.B.; STEELE, N.C. Response of low and high protein select lines of pigs to the feeding of the betaadrenergic agonist ractopamine (phenethanolamine). Journal of Animal Science, v.68, p.3226-3232, 1990.

MOORE, K.L.; DUNSHEA, F.R.; MULLAN, B.P. et al. Ractopamine supplementation increases lean deposition in entire and immunocastrated male pigs. Animal Production Science, v.49, p.1113-1119, 2009.

OLIVEIRA, A.L. Búfalos: produção, qualidade de carcaça e de carne: alguns aspectos quantitativos, qualitativos e nutricionais para promoção do melhoramento genético. Revista Brasileira de Reprodução Animal, v.29, p.122-134, 2005.

RIKARD-BELL, C.; CURTIS, M.A.; VAN-BARNEVELD, M.J. et al. Ractopamine hydrochloride improves growth performance and carcass composition in immunocastrated boars, intact boars, and gilts. Journal of Animal Science, v.87, p.3536-3543, 2009.

ROÇA, R.O. Propriedades da carne. Available at $<\mathrm{http}: / /$ pucrs campus2.br/ thompson/TPOA-Carne/Roca107.pdf $>$ Accessed on: Jun. 12, 2010.

SANCHES, J.F.; KIEFER, C.; MOURA, M.S. et al. Níveis de ractopamina para suínos machos castrados em terminação e mantidos sob conforto térmico. Ciência Rural, v.40, p.373-378, 2010.

SCHINCKEL, A.P.; RICHERT, B.T.; HERR, C.T. et al. Efeitos da ractopamina sobre o crescimento, a composição da carcaça e a qualidade dos suínos. In: CONFERÊNCIA INTERNACIONAL VIRTUAL SOBRE QUALIDADE DA CARNE SUÍNA, 2., 2001, Foz do Iguaçu. Anais... Foz do Iguaçu: EMBRAPA, 2001. p.1-12.

SMITH, W.C.; PURCHAS, R.W.; VAN-ENKEVORT, A. et al. Effects of ractopamine on the growth and carcass quality of entire male and female pigs fed ad libitum or at a restricted level. New Zealand Journal of Agricultural Research, v.38, p.373- 380, 1995.

STAHLY, T.S.; BARCK, L.J. Impact of somatotropin and betaadrenergic agonists in swine. In: MILLER, E.R.; ULLREY, D.E.; LEWIS, A.J. (Eds.). Swine nutrition. Stoneham: Butterworth Heinemann, 1991. chap. 6, p.103-117.

STITES, C.R.; MCKEITH, F.K.; SINGH, S.D. et al. The effect of ractopamine hydrochloride on the carcass cutting yields of finishing swine. Journal of Animal Science, v.69, p.3094-3101, 1991.

STOLLER, G.M.; ZERBY, H.N.; MOELLER, S.J. et al. The effect of feeding ractopamine (Paylean) on muscle quality and sensory characteristics in three diverse genetic lines of swine. Journal of Animal Science, v.81, p.1508-1516, 2003.

TARLADGIS, B.G.; PEARSON, A.M.; DUCAN Jr., L.R. Chemistry of the 2-tiobarbituric acid test for determination of oxidative rancity in foods. Journal Science Food Agricultury, v. 15, p.602-607, 1964.

UTTARO, B.E.; BALL, R.O.; DICK, P. et al.Effect of ractopamine and sex on growth, carcass characteristics, processing yield, and meat quality characteristics of crossbred swine. Journal of Animal Science, v.71, p.2439-2449, 1993.

VIRGILI, R.; DEGNI, M.; SCHIVAZAPPA, C. et al. Effect of age at slaughter on carcass traits and meat quality of Italian heavy pigs. Journal of Animal Science, v.81, p.2448-2456, 2003.

WARRIS, P.D.; BROWN, S.N.; ROLPH, T.P. et al. Interactions between the beta-adrenergic agonist salbutamol and genotype on meat quality in pigs. Journal of Animal Science, v.68, p.3669-3676, 1990. 
WATKINS, L.E.; JONES, D.J.; MOWREY, D.H. et al. The effect of various levels of ractopamine hydrochloride on the performance and carcass characteristics of finishing swine. Journal of Animal Science, v.68, p.3588-3595, 1990.

WOOD, J.D.; WISEMAN, J.; COLE, D.J.A. Control and manipulation of meat quality. In: COLE, D.J.A.; WISEMAN, J.; VARLEY,
M.A. (Eds.). Principles of pig science. London: Notthingham University, 1994. chap. 25, p.446-448.

XIAO, R.J.; XU, Z.R.; CHEN, H.L. Effects of ractopamine at different dietary protein levels on growth performance and carcass characteristics in finishing pigs. Animal Feed Science and Technology, v.79, p.119-127, 1999. 